\author{
Karolina Góralczyk \\ Uniwersytet w Białymstoku \\ karolina93goralczyk@gmail.com
}

\title{
Prawo do żądania nieudzielenia informacji jako wyraz autonomii pacjenta
}

\section{Right to demand the withholding of information as an expression of patient autonomy}

\begin{abstract}
Right to demand to withhold information is an expression of respect towards a patient's will and his autonomy as well as denial of the paternalistic conception of the relation between a sick patient and his doctor. It is the patient who, as a disposer of the right to information, decides if and to what extent he wants to receive it. Despite the fact that right to information has been widely described in medical law literature, the right to demand to withhold information, which is directly connected to it and is it's consequence, has not as yet been thoroughly examined. Because of that it seems right and reasonable to more closely analyse the issue of patient autonomy boundaries. It should be emphasised that none of the bills pertaining to the obligation to provide information, actually state that the patient has a right to not be informed of his state of health. The institution of demanding to withhold information raises many concerns while in medical practice it very often occurs. The following paper examines the scope of a patient's right to demand to withhold information as well as the circumstances of excluding and restricting that right. Also, it widely describes the consequences caused by the right to resign information. In particular, one part of the paper is devoted to the legal character of an expressed consent to treatment in accordance with opinions expressed in the legal doctrine.
\end{abstract}

Keywords: patient's rights, right to demand to withhold information, patient's autonomy

Słowa kluczowe: prawa pacjenta, prawo do żądania nieudzielenia informacji, autonomia pacjenta

\section{Uwagi wprowadzające}

Prawo do żądania nieudzielenia informacji jest wyrazem szacunku dla woli pacjenta, poszanowania jego autonomii ${ }^{1}$ i zaprzeczeniem paternalistycznej koncepcji

1 E. Zielińska (red.), Ustawa o zawodach lekarza i lekarza dentysty. Komentarz, Warszawa 2008, s. 450. 
relacji chorego z lekarzem². To pacjent jako dysponent prawa do informacji decyduje, czy i w jakim zakresie chce ją otrzymywać. Choć prawo do informacji doczekało się szerokiego omówienia $\mathrm{w}$ literaturze prawa medycznego, tak bezpośrednio $\mathrm{z}$ nim związane i będące jego następstwem prawo do nieinformowania nie zostało gruntownie przedstawione, przez co za słuszne i zasadne należy uznać przeanalizowanie przedstawionego problemu szczególnie związanego z kwestią granic autonomii pacjenta. Należy podkreślić, iż w żadnej dotychczas obowiązującej ustawie dotyczącej obowiązku informacji nie zaznaczano, że pacjent ma prawo do bycia niepoinformowanym o stanie zdrowia ${ }^{3}$. Instytucja żądania nieudzielenia informacji wywołuje wiele wątpliwości, a w praktyce medycznej pojawia się nader często. Problemem jest bez wątpienia sama natura tego prawa będącego wyjątkiem ${ }^{4}$ od utrwalonej w doktrynie i orzecznictwie ogólnej reguły informowania pacjenta oraz zasady informed consent to therapy. Wynikiem czego są wątpliwości związane $\mathrm{z}$ ustaleniem zakresu zrzeczenia się informacji, ewentualnym ograniczeniem prawa do żądania jej nieudzielenia - wyłączeniem prawa do nieinformowania, a w następstwie powyższych realizacja żądania nieprzekazania informacji i jej wpływ na skuteczność zgody wyrażonej przez pacjenta oraz pojawiające się na tym tle dylematy etyczne i prawne.

Prawo do żądania nieudzielenia informacji zostało uregulowane w art. 9 ust. 4 ustawy o prawach pacjenta i Rzeczniku Praw Pacjenta ${ }^{5}$, który przyznaje pacjentowi prawo do żądania nieudzielenia informacji o stanie zdrowia, rozpoznaniu, proponowanych oraz możliwych metodach diagnostycznych i leczniczych, dających się przewidzieć następstwach ich zastosowania albo zaniechania, wynikach leczenia oraz rokowaniu. Pacjent może zrezygnować z całości lub części przysługujących mu informacji - musi wyraźnie wskazać zakres informacji, z jakich rezygnuje. Podobna regulacja została zawarta w art. 31 ust. 3 ustawy o zawodach lekarza i lekarza dentysty, zgodnie z którym lekarz nie ma obowiązku informowania pacjenta na jego żądanie oraz w art. 16 Kodeksu Etyki Lekarskiej ${ }^{78}$. Obydwa przepisy korespondują ze sobą, podobnie jak prawo pacjenta do nieinformowania i wyjątek od obowiązku informowania pacjenta, spoczywający na lekarzu. Prawo do żądania nieudzielenia informacji zostało uregulowane w schematyczny sposób, przez co też i w doktrynie, zgodnie $\mathrm{z}$ ustawową regulacją, wskazuje się jedynie, że zwolnienie lekarza $\mathrm{z}$ obowiązku informowania pacjenta jest wyznaczane zakresem żądania samego pacjenta9. Należy

2 J. Bujny, Prawa pacjenta między autonomią a paternalizmem, Warszawa 2007, s. 148.

3 A. Górski, O obowiązku lekarza poinformowania pacjenta i zgodzie pacjenta na zabieg, „Studia luridica” nr 39 , 2001, s. 85.

4 T. Dukiet- Nagórska, Stosowanie ustawy o zawodzie lekarza przez psychiatrów i ustawy o ochronie zdrowia psychicznego przez lekarzy innych specjalności, „Prawo i Medycyna” 2004, nr 4, (17 vol. 6), s. 9.

Tekst jedn. Dz.U. z 2016 r. poz. 186, dalej u.p.p.

Tekst jedn. Dz.U. z 2017 r. poz. 125, dalej u.z.I.

Kodeks Etyki Lekarskiej, Obwieszczenie nr 1/04/IV Prezesa Naczelnej Rady Lekarskiej z dnia 2 stycznia 2004 r. w sprawie ogłoszenia jednolitego tekstu uchwały w sprawie Kodeksu Etyki Lekarskiej. kryterium odniesienia dla oceny prawidłowości wykonywania profesji medycznej. 
jednak zaznaczyć, że takie stwierdzenie jest nader ogólne i można je stosować tylko w typowych przypadkach, których w praktyce jest stosunkowo mało.

Celem uporządkowania niniejszego artykułu oraz dbając o rzetelność przekazu, trzeba wskazać na krąg podmiotów, którym przysługuje omawiane prawo i choć bez wątpienia należą do niego sami pacjenci, warto rozważyć czy prawo do nieinformowania przysługuje również przedstawicielowi ustawowemu pacjenta. W doktrynie ukształtowało się stanowisko, zgodnie z którym małoletni pacjent, także ten, który ukończył 16 lat, może żądać nieudzielenia informacji, natomiast tego prawa odmawia się jego przedstawicielowi ustawowemu ${ }^{10}$. Istotna jest sama forma żądania, które powinno być wyrażone w sposób bezpośredni, niebudzący wątpliwości ${ }^{11}$, wyraźny, stanowczy, ukazujący zdecydowanie pacjenta (nie można zaniechać informowania na podstawie dorozumianej $z g o d y^{12}$ ) oraz - ze względów dowodowych zostać oznaczone w dokumentacji medycznej ${ }^{13}$. W doktrynie pojawił się pogląd ${ }^{14}$, iż już samo brzmienie przepisu wskazuje na to, że zgoda nie może być wyrażona w sposób dorozumiany, ale ma być żądaniem weryfikowanym według surowych kryteriów. Lekarz nie może zaprzestać informowania na podstawie dorozumianego zachowania pacjenta, np. zaniechania zadawania pytań przez pacjenta. Pacjent jako dysponent prawa do informacji w każdej chwili może wznowić chęć informowania i wówczas jest informowany na zasadach ogólnych ${ }^{15}$. W doktrynie podkreśla się, iż zrzeczenie musi być aktywne i uzewnętrznione ${ }^{16}$.

Przyczyny zrzeczenia się prawa do informacji mogą być zróżnicowane: pacjent może nie interesować się swoim stanem zdrowia, nie chcieć słuchać informacji z tym związanych, może odczuwać wstręt do treści przekazywanych informacji ${ }^{17}$ oraz żądanie może być wynikiem pełnego zaufania lekarzowi ${ }^{18}$. Powody zrzeczenia są zależne od pacjenta ${ }^{19}$ i nie podlegają ocenie lekarza. W praktyce żądanie najczęściej występuje, gdy pacjent znajduje się w stanie ciężkim i sam podejrzewa u siebie niepomyślne rokowanie, wówczas nie chce być informowany przez lekarza o swoim stanie zdrowia ${ }^{20}$. W doktrynie wskazuje się na nadrzędność tzw. prawa do prawdy, które ulega ograniczeniu z uwagi na fakt, iż pacjent może nie chcieć wiedzieć wszystkiego,

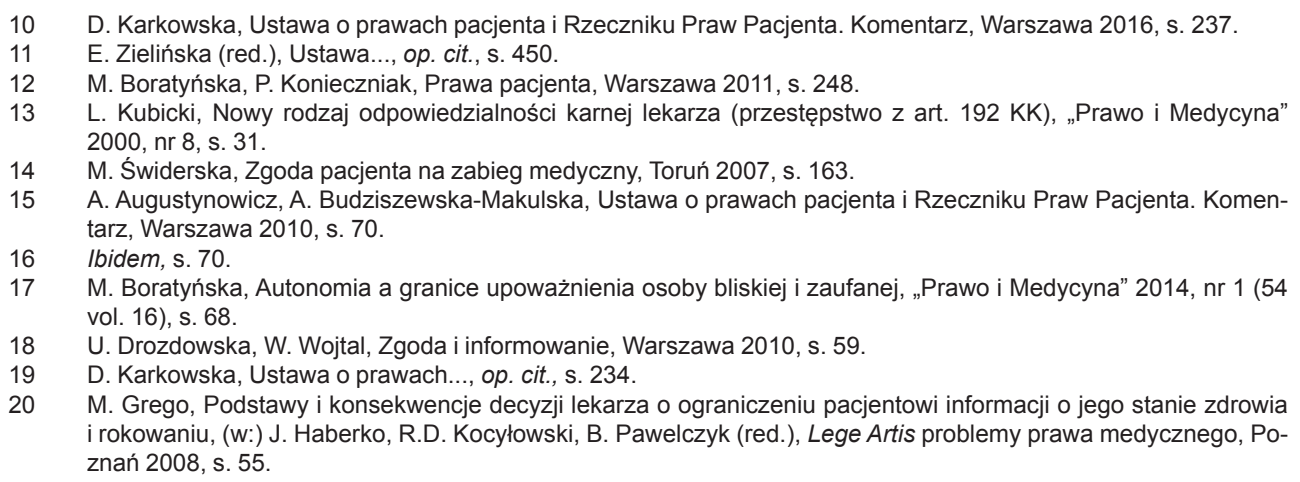

20 M. Grego, Podstawy i konsekwencje decyzji lekarza o ograniczeniu pacjentowi informacji o jego stanie zdrowia i rokowaniu, (w:) J. Haberko, R.D. Kocyłowski, B. Pawelczyk (red.), Lege Artis problemy prawa medycznego, Poznań 2008, s. 55. 
w szczególności niepomyślnych rokowań, jakie mogą pogorszyć jego stan psychiczny i fizyczny ${ }^{21}$. Żądanie nieudzielenia informacji nie jest zrzeczeniem się prawa w rozumieniu cywilistycznym, bowiem przedmiotem prawa do informacji jest dobro osobiste pacjenta - autonomia informacyjna ${ }^{22}$.

\section{Zakres prawa pacjenta do żądania nieudzielenia informacji}

Zakres prawa do żądania nieudzielenia informacji nie jest określony w przepisach obowiązującego prawa. W doktrynie wskazuje się jednak, iż zależy od pacjenta, ponieważ to on jako dysponent prawa do informowania, decyduje, z których informacji i w jakim stopniu rezygnuje. Wpływ na kształt przekazywanych informacji ma również lekarz, oceniający jako profesjonalista medyczny, których informacji pacjent może się zrzec z uwagi na swoje dobro i dobro innych osób. Ponadto należy zaznaczyć, iż istnieją przypadki wyłączenia stosowania art. 9 ust. 4 u.p.p. i art. 31 ust. 3 u.z.l. z mocy samego prawa.

W doktrynie pojawiły się rozmaite koncepcje zakresu zrzeczenia prawa do informacji. Najszerzej reprezentowane są następujące poglądy: pierwszy z nich wyróżnia możliwość całkowitego zrzeczenia się informacji, gdzie lekarz zwolniony jest $\mathrm{z}$ udzielenia jakichkolwiek informacji oraz drugi, $\mathrm{tj}$. profesjonalista medyczny jest zwolniony tylko z określonych informacji ${ }^{23}$. Minimalną różnicę możemy zauważyć w koncepcji przedstawionej przez E. Zielińską, według której pacjent ma prawo wskazać, iż nie chce otrzymywać szczegółowych informacji lub być w ogóle poinformowany o niektórych aspektach planowanych zabiegów ${ }^{24}$. Ten zakres nieprzekazywanych informacji zakreślony jest węziej, gdyż ogranicza się do szczegółowych informacji i niektórych aspektów, co więcej literalnie nie wymienia możliwości całkowitego zrzeczenia się prawa do informacji. Najwęziej prawo do bycia nieinformowanym przedstawia K. Michałowska, według której zakres umożliwiający zrzeczenie się w obszarze wyznaczonym art. 31 ust. 1 u.p.p. jest zbyt szeroki - jest całkowitym odstąpieniem od obowiązku udzielenia informacji i powinien zostać zawężony ${ }^{25}$. Informacja może być ograniczona tylko do takiej, która nie będzie negatywnie wpływać na psychikę pacjenta, bowiem lekarz nie może nie wypełniać obowiązku informowania pacjenta ${ }^{26}$. Odmienne stanowisko prezentuje J. Bujny, którego zdaniem pacjent w dowolny sposób dysponuje swoim prawem do informacji, a wszelkie próby jego ograniczenia i nierespektowania jego woli są przejawem braku szacunku dla woli

21 M. Nesterowicz, Prawo medyczne, Toruń 2016, s. 189.

22 U. Drozdowska, Cywilnoprawna ochrona prawa pacjenta, Warszawa 2007, s. 148.

23 A. Augustynowicz, A. Budziszewska-Makulska, Ustawa..., op. cit., s. 70; D. Karkowska, op. cit., s. 234.

24 E. Zielińska (red.), Ustawa..., op. cit., s. 480.

25 K. Michałowska, Charakter prawny i znaczenie zgody pacjenta na zabieg, Warszawa 2014, s. 160.

26 K. Michałowska, Informowanie pacjenta w polskim prawie medycznym, „Prawo i Medycyna” 2003, nr 13 (vol. 5), s. 115 . 
Prawo do żądania nieudzielenia informacji jako wyraz autonomii pacjenta

chorego, ingerencją w jego autonomię ${ }^{27}$. Na gruncie praktycznej wykładni zakresu zrzeczenia korzystania z prawa do informacji należy rozważyć następujące kwestie: czy wszystkich informacji pacjent może się zrzec, również tych związanych z ryzykiem zabiegu oraz rokowaniem. Przy uznaniu, iż to pacjent jest dysponentem swojego prawa oraz decyduje o jego kształcie w sensie podmiotowym (przez uprawnienie innych osób do informowania) oraz przedmiotowym (co do rodzaju i zakresu informacji) należy stwierdzić, że może według własnego uznania żądać ograniczenia informacji lub prosić o ich przemilczenie ${ }^{28}$.

\section{Okoliczności wyłączenia lub ograniczenia prawa do żądania nieudzielenia informacji}

Rozważając kwestię zakresu prawa do żądania nieudzielenia informacji należy zaznaczyć, że nie jest to prawo bezwzględne i nieograniczone. Odmienne stanowisko przyjmuje jednak M. Boratyńska, zdaniem której określone w art. 31 ust. 3 u.z.l. prawo do żądania nieudzielenia informacji jest wyraźnie określone i nieograniczone $^{29}$. Co prawda brzmienie art. 9 ust. 4 u.p.p. wskazuje na jego bezwzględny charakter - „pacjent ma prawo żądać”, jednakże regulacja zawarta w art. 31 ust. 3 u.z.l. ma charakter nieco bardziej dyspozytywny - „lekarz nie ma obowiązku udzielać pacjentowi informacji”. Zauważalnym jest, że przepis zdejmuje z lekarza zobowiązanie do udzielenia informacji, ale nie nakłada na niego bezwzględnego obowiązku nieinformowania na żądanie pacjenta, należy więc dopuścić sytuacje, w których niechciana informacja zostaje pacjentowi udzielona. Powyższa wykładnia znajduje swoje uzasadnienie w fakcie, iż obowiązek informowania (udzielenie informacji we właściwy sposób, o odpowiednim zakresie) jest traktowany jako jeden z najważniejszych obowiązków lekarza. Wątpliwym byłoby więc nałożenie na lekarza obowiązku uwzględniania żądań pacjentów w sposób bezwzględny i nieograniczony, bez umożliwienia profesjonaliście medycznemu decydowania ad casu.

Mimo uznania, iż pacjent jest dysponentem prawa do informacji, celem omawianego prawa (oprócz zapewnienia mu podmiotowego traktowania) jest również zagwarantowanie należytego przebiegu leczenia, właściwej współpracy z lekarzem, a także - w wybranych przypadkach - ochrony praw osób trzecich. Istnieją dwie możliwości wyłączenia lub ograniczenia prawa do żądania nieudzielenia informacji. Pierwsza z nich to ograniczenie z mocy ustawy, druga - jak się wydaje - wynika $\mathrm{z}$ decyzji samego lekarza, który z uwagi na dobro pacjenta, przy uwzględnieniu toku leczenia oraz znaczenia informacji dla ewentualnej zgody pacjenta zdecyduje się na informowanie pacjenta wbrew jego żądaniu.

\footnotetext{
27 J. Bujny, Prawa pacjenta..., op. cit., s. 148.

28 U. Drozdowska, W. Wojtal, Zgoda..., op. cit., s. 60.

29 M. Boratyńska, Autonomia..., op. cit., s. 68.
} 
Ustawowe wyłączenie prawa do nieinformowania zachodzi w przypadku pacjenta zakażonego, z zaburzeniami psychicznymi, poddawanego eksperymentom medycznym, zabiegowi transplantacji, kobiet decydujących się na zabieg przerwania ciąży, kobiet biorczyń gamet (zarodków) i mężczyzn dawców nasienia na podstawie ustawy o leczeniu niepłodności ${ }^{30}$. Szczegółowo należy przyjrzeć się sytuacjom, w których pacjent $z$ mocy prawa nie może zrzec się uprawnienia do bycia informowanym, które dotyczy zarówno informacji o „Zwykłym”, jak i podwyższonym ryzyku. Należy podkreślić, iż w medycynie nie ma „przymusu informacji” $\mathrm{z}$ wyjątkiem przesłanek ustawowych, które zostaną omówione ${ }^{31}$.

Wyłączenie prawa do nieinformowania występuje w przypadku osób zakażonych nie tylko $\mathrm{z}$ uwagi na ich proces leczenia, ale również w celu zapewnienia bezpieczeństwa osób trzecich. Takie skorzystanie z prawa pacjenta do niewiedzy mogłoby narazić postronne osoby na niebezpieczeństwo ${ }^{32}$. Osoba podejrzana o zachorowanie, chora lub narażona na zakażenie, $\mathrm{z}$ uwagi na specyfikę swojego stanu, jest nie tylko informowana, ale również (zgodnie $\mathrm{z}$ art. 35 ust. 1 ustawy z dnia 5 grudnia 2008 r. o zapobieganiu oraz zwalczaniu zakażeń i chorób zakaźnych u ludzi ${ }^{33}$ ) hospitalizowana wbrew swojej woli. Ponadto pacjent zakażony nie może zrzec się informacji z uwagi na bezpieczeństwo innych osób; w tej sytuacji jego autonomia wyrażona $\mathrm{w}$ prawie do nieinformowania ustępuje na rzecz prawa innych osób. Na podstawie art. 39 u.z.z.ch., w przypadku rozpoznania zakażenia, które może przenosić się drogą kontaktów seksualnych, lekarz lub felczer ma obowiązek poinformować zakażonego o konieczności zgłoszenia się do lekarza partnera lub partnerów seksualnych zakażonego, ten obowiązek pozbawia pacjenta prawa do nieinformowania. $Z$ uwagi na treść art. 26 u.z.z.ch., ściśle określony personel medyczny - lekarz, felczer, pielęgniarka lub położna - obowiązany jest pouczyć zakażonego m.in. o środkach służących zapobieganiu przeniesienia zakażenia na inne osoby, w przypadku rozpoznania zakażenia, które może przenosić się drogą kontaktów seksualnych, poinformować zakażonego konieczności zgłoszenia się do lekarza partnera lub partnerów seksualnych zakażonego. Przepis nie pozwala pacjentowi na rezygnację z informacji koniecznych. Prawo do niepoznania informacji ustępuje prawom innych osób ${ }^{34}$.

Szczególnie regulowana jest również sytuacja pacjenta szpitala psychiatrycznego w ustawie z dnia 19 sierpnia 1994 r. o ochronie zdrowia psychicznego ${ }^{35}$. Przepisy normują przymusowe leczenie pacjenta przyjętego bez zgody, w przypadku którego na lekarza nakłada się obowiązek informowania pacjenta o planowanym postępowaniu. Osoby z zaburzeniami są informowane o celu przyjęcia do szpitala psychiatrycznego, stanie zdrowia, proponowanych czynnościach diagnostycznych i leczniczych,

D. Karkowska, Ustawa..., op. cit., s. 237.

U. Drozdowska, W. Wojtal, Zgoda..., op. cit., s. 59

U. Drozdowska, Cywilnoprawna..., op. cit., s. 148.

Tekst jedn. Dz.U. z 2016 r. poz. 1866 dalej, u.z.z.ch.

D. Karkowska, Ustawa... op. cit., s. 236.

Tekst jedn. Dz.U. z 2017 r. poz. 882. 
Prawo do żądania nieudzielenia informacji jako wyraz autonomii pacjenta

oraz dających się przewidzieć skutkach tych działań. Z uwagi na szczególne ograniczenie autonomii pacjenta szpitala psychiatrycznego, nie może on być pozbawiony prawa do wskazanych informacji.

Prawo do nieinformowania jest wyłączone w przypadku osób poddawanych eksperymentom medycznym. Pacjenci na podstawie regulacji zawartej w art. 24 u.z.l. informowani są o celach, sposobach, warunkach przeprowadzenia eksperymentu, spodziewanych korzyściach leczniczych lub poznawczych, ryzyku oraz możliwości odstąpienia od udziału w eksperymencie w każdym jego stadium. Są to zabiegi o charakterze nieleczniczym i wymagają zawsze pełnej informacji, pacjent nie może się jej zrzec ${ }^{36}$. Eksperymenty badawcze, lecznicze oraz badania kliniczne mają wiele wspólnych cech, m.in. obowiązek poinformowania osoby poddającej się eksperymentowi ${ }^{37}$. Należy wskazać, iż eksperyment medyczny nie zawsze jest czynnością leczniczą, z uwagi na to prawo zakazuje eksperymentów bez dobrowolnie wyrażonej zgody, w omawianym przypadku nie stosuje się przepisów ogólnych dotyczących zgody na leczenie ${ }^{38}$.

Osobami o szczególnych przywilejach informacyjnych są również kandydaci na żywych dawców komórek tkanek i narządów, a także biorcy. Zgodnie z art. 12 ust. 1 pkt 5 ustawy z dnia 1 lipca 2005 r. o pobieraniu, przechowywaniu i przeszczepianiu komórek, tkanek i narządów ${ }^{39}$ dawca przed wyrażeniem zgody jest szczegółowo informowany na piśmie o rodzaju zabiegu, ryzyku związanym z tym zabiegiem i o dających się przewidzieć następstwach dla jego stanu zdrowia w przyszłości. Podobnie kandydat na biorcę, na postawie art. 12 ust. 1 pkt 9 u.p.p.p. jest informowany o ryzyku związanym z zabiegiem pobrania komórek, tkanek lub narządu oraz o możliwych następstwach pobrania dla stanu zdrowia dawcy.

Osobami o szczególnych przywilejach informacyjnych są kobiety ciężarne, które mają prawo do uzyskania informacji na temat badań prenatalnych, szczególnie wtedy gdy istnieje podwyższone ryzyko wystąpienia wady genetycznej i rozwojowej płodu albo nieuleczalnej choroby zagrażającej życiu płodu ${ }^{40}$ (art. 2 ust. 2a ustawy o planowaniu rodziny ${ }^{41}$ ). Prawo żądania nieudzielania informacji jest wyłączone również w stosunku do kobiety, która chce przerwać ciążę (art. 4a u.p.r.).

Ostatnią szczególną regulacją jest zawarty w ustawie o leczeniu niepłodności obowiązek przekazywania informacji kobiecie jako biorcy i mężczyźnie jako dawcy ${ }^{42}$, jak również osobom, względem których podjęto czynności związane z zapłodnieniem pozaustrojowym. Ustawowym bezwzględnym warunkiem pobierania od dawcy

\footnotetext{
36 D. Karkowska, Ustawa..., op. cit., s. 235.

37 W. Nowak, Prawne formy zgody pacjenta na eksperyment medyczny (zagadnienie cywilnoprawne), „Prawo i Medycyna" 2005, nr 3 (20, vol. 7), s. 47.

38 A. Górski, Leczyć czy nie leczyć? Dylematy podejmowania leczenia z punktu widzenia konfliktu dóbr, „Czasopismo Prawa Karnego i Nauk Penalnych", Rok XV: 2011, s. 160.

Tekst jedn. Dz.U. z 2017 r. poz. 1000, dalej u.p.p.p.

D. Karkowska, Ustawa..., op. cit., s. 221.

Dz.U. z 1993 r., Nr 17 ze zm., poz. 78, dalej u.p.r.

Tekst jedn. Dz.U. z 2017 r. poz. 865.
} 
komórek rozrodczych jest udzielenie zrozumiałych i szczegółowych informacji przez przygotowaną do tego celu osobę o rodzaju zabiegu, jego charakterze, przeprowadzonych dla jego wykonania badaniach laboratoryjnych oraz prawie do uzyskania wyników tych badań, sposobie gromadzenia i ochrony jego danych osobowych, tajemnicy lekarskiej, ryzyku związanym z zabiegiem pobierania komórek rozrodczych, dających się przewidzieć następstwach dla jego stosowania w przyszłości, środkach bezpieczeństwa etc. Analogiczne wymogi stawiane są co do kobiety biorczyni.

Druga możliwość wyłączenia lub ograniczenia prawa do żądania nieudzielenia informacji wynika $\mathrm{z}$ dyspozytywnego brzmienia art. 31 ust. 3 u.z.l., w myśl którego lekarz nie ma obowiązku udzielać informacji pacjentowi. Wykładnia ta wynika z faktu, iż nie można nałożyć na lekarza obowiązku nieinformowania, czyli niejako zakazu informowania i ze specyfiki stosunków, jakie poddawane są analizie. Można dopuścić sytuację (poza omówionymi wynikającymi z ustawy), w której lekarz z uwagi na rokowanie, radykalność i nieodwracalność danego zabiegu medycznego, np. amputację kończyny, zabieg sterylizacji, będzie informował pacjenta wbrew jego woli ${ }^{43}$. Żądanie pacjenta w tak wyjątkowych okolicznościach nie może uchylać obowiązku lekarza, ponieważ pacjent nie może być pozbawiony informacji o celu zabiegu, jaki łączy się np. z nieodwracalnym usunięciem części jego ciała ${ }^{44}$. Niepoinformowanie wywołałoby bardziej traumatyczne skutki, niż reakcja na udzieloną informację. Ponadto pełnej informacji wymagają zabiegi nielecznicze. Ich charakter przesądza o pełnym informowaniu pacjenta i wyłącza ochronę autonomii woli pacjenta odmawiającego informacji ${ }^{45}$.

Spór $\mathrm{w}$ doktrynie pojawia się również $\mathrm{w}$ kwestii zrzeczenia się prawa do informacji przy zabiegach o podwyższonym ryzyku. W doktrynie przyjęty jest pogląd, iż takie zrzeczenie jest dopuszczalne także i w tym przypadku, $\mathrm{z}$ uwagi na odesłanie do art. 31 u.z.l., zawarte w art. 34 ust. 2 u.z.l., zgodnie z którym przed wyrażeniem zgody przez pacjenta na zabieg operacyjny lub zastosowanie metody leczenia lub diagnostyki stwarzającej podwyższone ryzyko u pacjenta, lekarz ma obowiązek udzielenia $\mathrm{mu}$ informacji zgodnie $\mathrm{z}$ art. 31 u.z.l. Ponadto ratio legis dopuszczalności zrzeczenia się przez pacjenta informacji jest ochrona autonomii woli pacjenta ${ }^{46}$. Odmienny pogląd prezentuje M. Filar, zdaniem którego brzmienie art. 31 u.z.l. przemawia za bezwzględnym obowiązkiem informowania przy zabiegach operacyjnych i innych stwarzających podwyższone ryzyko ${ }^{47}$.

Za zbyt daleko idący należy uznać zgłoszony w doktrynie pogląd, iż gdy pacjent nie chce być informowany, lekarz nie może nie wypełniać ciążącego na nim obowiązku informowania. Lekarz powinien jedynie ograniczyć zakres informacji do

\footnotetext{
43 D. Karkowska, Ustawa..., op. cit., s. 235; M. Sośniak, Cywilna odpowiedzialność lekarza, Warszawa 1968, s. 47.

44 M. Świderska, Zgoda..., op. cit., s. 169.

45 Ibidem, s. 169.

46 Ibidem, s. 163-164.

47 M. Filar, Lekarskie prawo karne, Kraków 2000, s. 264-265.
} 
tych, które nie będą negatywnie wpływały na psychikę pacjenta ${ }^{48}$. Z uwagi jednak na dyspozytywność art. 31 ust. 3 u.z.l. oraz przyznanie lekarzowi w wyjątkowych sytuacjach prawa do informowania wbrew woli pacjenta, zapobiegniemy obawom wynikającym z następstw, jakie dana informacja może wywołać w toku leczenia. Choć podnosi się, że zaleceń dotyczących trybu życia czy farmakoterapii nie należy utożsamiać $\mathrm{z}$ informacjami przed zabiegiem, które stanowią element zgody ${ }^{49}$. W takich sytuacjach lekarz jest obowiązany do podjęcia dialogu z pacjentem, być może próby zmiany decyzji pacjenta dotyczącej żądania nieinformowania, celem wypełniania obowiązku informowania lege artis. Za słuszny należy uznać tu postulat zdefiniowania warunków zrzeczenia się $e^{50}$.

\section{Wyrażenie zgody na leczenie w świetle żądania nieudzielenia informacji}

Prawo pacjenta do żądania nieudzielenia informacji wywołuje konsekwencje w kwestii charakteru prawnego wyrażonej zgody na leczenie, a w doktrynie pojawiają się różne jej koncepcje. Problem jest niezwykle ważny z uwagi na fakt, iż właściwie wyrażona zgoda wyłącza możliwość dowolnego podejmowania terapii przez personel medyczny ${ }^{51}$. Problem wynika z kolizji, w jakiej pozostają z jednej strony prawo do żądania nieudzielenia informacji, którego dysponentem jest sam pacjent, z drugiej zaś trudność oceny zgody wyrażonej wobec niepoinformowania pacjenta. Charakter prawny zgody wyrażonej przez pacjenta, który zrzekł się prawa do informacji, wynika z przesłanek niewadliwości zgody, według których oświadczenie woli nie może być dotknięte wadami oświadczeń woli - wyrażenie zgody w sposób świadomy po uprzednim poinformowaniu - realizacja zasady informed consent ${ }^{52}$. Jednakże należy zaznaczyć, iż wobec dopuszczonego ustawowo wyjątku w postaci możności nieudzielenia pacjentowi informacji, z jednej strony nie może on wyrazić zgody na czynności, o których nie posiada żadnej wiedzy, a z drugiej ma prawo do nieinformowania ${ }^{53}$.

Przez żądanie nieudzielenia informacji następuje wyrażenie zgody niepoinformowanej, określanej mianem zgody blankietowej, której istotą jest udzielenie lekarzowi ogólnego upoważnienia do działania zgodnie z posiadaną przez niego wiedzą ${ }^{54}$. W doktrynie podniesiono, że pacjent ma prawo zrzec się informacji i jest to jedyny przypadek zgody blankietowej, która uchyla bezprawność, a sama zgoda nie jest wadliwa, jeżeli pacjent tego żądał. Ujawnienie informacji nie jest jedynym warunkiem prawomocności zgody, ale pacjenci nie mogą podjąć rozsądnej decyzji o leczeniu bez

\footnotetext{
K. Michałowska, Informowanie..., op. cit., s.107.

M. Świderska, Zgoda..., op. cit., s. 165.

M. Boratyńska, P. Konieczniak, Prawa..., op. cit., s. 248.

A. Górski, Leczyć, czy nie leczyć?, Dylematy..., op. cit., s. 153.

U. Drozdowska, W. Wojtal, Ustawa..., op. cit., s. 16.

K. Michałowska, Charakter prawny..., op. cit., s. 159.

Ibidem, s. 159.
} 
posiadania wiedzy na temat pewnych faktów znanych personelowi medycznemu ${ }^{55}$. Zrzeczenie się informacji może być połączone $\mathrm{z}$ upoważnieniem osoby zaufanej, które ma charakter zastępczy, a informowanie odbywa się „ponad głową pacjenta”. Upoważnienie osoby zaufanej następuje z tzw. ostrożności, np. na wypadek błędu medycznego; w takich przypadkach osoba zaufana jest jedynym odbiorcą informa$\mathrm{cji}^{56}$. Według prezentowanego stanowiska, w istocie zrzeczenie prawa do informacji nie oznacza zrzeczenia się prawa do wyrażenia zgody na leczenie, ale jest to zgoda blankietowa. Przez żądanie nieudzielenia informacji zaistniał jedyny przypadek w naszym systemie prawnym, kiedy zgoda na leczenie w ogóle lub zgoda na leczenie ogólnikowo zdefiniowanym sposobem, może być stosowana ${ }^{57}$.

Według odmiennej koncepcji, uzyskiwanie zgody blankietowej od pacjenta jest prawnie nieskuteczne. Pacjent, wyrażając zgodę musi otrzymać informację, a działanie lekarza w obliczu odstąpienia od informowania na żądanie pacjenta będzie zgodne z prawem, ale sama zgoda będzie pozbawiona znaczenia prawnego ${ }^{58}$. Podobne założenie zostało przyjęte $\mathrm{w}$ doktrynie; w przypadku zrzeczenia się prawa do informacji przekreślona zostaje możliwość wyrażenia przezeń świadomej zgody ${ }^{59}$.

Zupełnie odmienny i jak się wydaje najbardziej akceptowalny pogląd oddziela koncepcję zgody blankietowej od żądania nieudzielenia informacji. Okoliczność żądania nieudzielenia informacji powoduje uchylenie jednego z elementów konstrukcji skutecznej zgody, bowiem pacjent przez swoje oświadczenie o odmowie przyjęcia informacji znosi „element informacji”. Istotą zgody blankietowej jest akceptacja wszelkich interwencji medycznych, wyrażona przez pacjenta niepoinformowanego, który nie zgłaszał żądania by nie udzielano mu informacji. Zgoda blankietowa nie wywiera jednak skutków prawnych ${ }^{60}$.

\section{Lekarz wobec prawa pacjenta do żądania nieudzielenia informacji}

Pomimo, iż żądnie nieudzielenie informacji jest prawem pacjenta, z uwagi na fakt, iż chory przekazuje lekarzowi odpowiedzialność i prawo do podjęcia decyzji, lekarz pełni istotną rolę w procedurze żądania nieudzielenia informacji. Z uwagi na powyższe, należy omówić warunki zrzeczenia się prawa do informacji jakie może zapewnić lekarz.

W doktrynie wskazuje się, iż lekarz, spełniając wymóg należytej staranności, powinien ponawiać pytanie, czy na pewno pacjent zrzeka się prawa do informacji, także co do ewentualnych następstw o dużym znaczeniu, pytać o ewentualne wyzna-

\footnotetext{
55 M. Boratyńska P. Konieczniak, Prawa..., op. cit., s. 246.

56 M. Boratyńska, Autonomia..., op. cit., s. 68.

57 M. Boratyńska P. Konieczniak, Prawa..., op. cit., s. 248.

58 Ibidem, s. 160.

59 T. Dukiet-Nagórska, Świadoma zgoda w ustawodawstwie polskim, „Prawo i Medycyna” 2000, nr 2 (6/7 vol. 2), s. 80 .

60 M. Świderska, Zgoda..., op. cit., s. 164-165.
} 
Prawo do żądania nieudzielenia informacji jako wyraz autonomii pacjenta

czenie osoby upoważnionej do uzyskania informacji w jego imieniu. Wobec zrzeczenia lekarz powinien informować o koniecznych wymogach i skutkach dokonania zabiegu, np. potrzebie zachowania określonej diety. Ponadto nie należy utożsamiać informacji przed zabiegiem z zaleceniami po zabiegu dotyczącymi trybu życia pacjenta, uprzednie zrzeczenie się pacjenta nie ma tu znaczenia ${ }^{61}$. Należy podkreślić, że niedopuszczalnym jest wywieranie nacisków przez personel medyczny na pacjenta celem osiągnięcia jego zrzeczenia oraz sugerowanie pacjentowi, iż może się zrzec informacji na rzecz swobodnej decyzji lekarza ${ }^{62}$. Kontynuując wątek nadużyć na tym tle, należy wskazać na możliwość nadużyć związanych z pozbyciem się uciążliwych i czasochłonnych procedur pobierania zgody poinformowanej, zwłaszcza w dużych placówkach, przy dużej liczbie przyjętych pacjentów, gdzie istnieje ryzyko, że lekarze przy aprobacie administracji będą nakłaniali do zrzeczenia się tego prawa ${ }^{63}$. Ponadto lekarz nie może sugerować pacjentowi skorzystania $\mathrm{z}$ prawa do zrzeczenia $\mathrm{z}$ uwagi na jego dobro czy niezrozumienie informacji ${ }^{64}$.

Trafny wydaje się zgłoszony w doktrynie pogląd, iż poinformowanie pacjenta o jego stanie zdrowia, mimo że sobie tego nie życzył, bądź przekazywanie pełnej informacji o jego stanie zdrowia, chociaż jej nie żądał, stanowi uchybienie obowiązkowi informowania ${ }^{65}$. W konsekwencji należy rozważyć, czy w przypadku informowania pacjenta wbrew jego woli, w sposób nieuzasadniony, lekarz udziela pacjentowi informacji nadmiernej. Zgodnie $\mathrm{z}$ zaproponowaną $\mathrm{w}$ literaturze definicją, informacja nadmierna to informacja, która może doprowadzić do wyrządzenia pacjentowi szkody. W świetle tej definicji, informacja przekazywana wbrew żądaniu może stanowić informację nadmierną, o ile spowoduje szkodę u pacjenta. Jednakże w doktrynie podkreśla się, iż lekarz nie może odpowiadać za udzielenie informacji nadmiernej, ponieważ ustawowa konstrukcja informacji jest wadliwa i implikuje udzielanie przez lekarzy informacji nadmiernych. Ponadto termin ten jest trudny do zdefiniowania, co niejako wyklucza odpowiedzialność za jej udzielenie oraz powoduje trudności w sprecyzowaniu granic odpowiedzialności ${ }^{66}$. W konsekwencji lekarz nie może być pociągnięty do odpowiedzialności za udzielenie informacji nadmiernej.

Należy jednak wskazać na sytuację, w której lekarz nie respektując żądania nieinformowania naraża się na odpowiedzialność za szkodę wyrządzoną przez tę informację. Pacjent poinformowany wbrew woli może ze względu na stan swojego zdrowia i stan psychiczny np. popaść w depresję ${ }^{67}$. Per analogiam można tu przytoczyć przykład informowania w warunkach przywileju terapeutycznego, gdzie wyrokiem Sądu

\footnotetext{
61 Ibidem, s. 165-166.

62 D. Karkowska, Ustawa..., op. cit, s. 234.

63 Opisywane zjawisko występuje już na zachodzie na dużą skalę; M. Boratyńska, P. Konieczniak, Prawa..., op. cit., s. 247.

64 M. Świderska, Zgoda..., op. cit., s. 166.

65 A. Górski, Leczyć..., op. cit., s. 90-91.

66 R. Tymiński, Odpowiedzialność lekarza za udzielenie informacji nadmiernej, Prawo i Medycyna 2012 , nr 1 (46 vol. 14), s. 57.

67 A. Górski, Leczyć..., op. cit., s. 92.
} 
Okręgowego Wyższego w Kolonii sąd uznał lekarza odpowiedzialnym za szkodę, gdy wprost powiedział pacjentowi o nowotworze mózgu i niepewności co do mającej nastąpić terapii. Pacjent po otrzymaniu informacji doznał szoku i wstrząsu psychicznego do tego stopnia, że rozwinęła się u niego choroba serca i częściowy paraliż w mówieniu. Zdaniem sądu, mimo prawa lekarza do udzielenia informacji, ujawnienie informacji w takiej formie naruszyło to prawo ${ }^{68}$. Niniejszy problem jest bardzo delikatny z uwagi na to, iż skutki informacji mogą okazać się nieodwracalne ${ }^{69}$ oraz trudne jest wyważenie pomiędzy prawem pacjenta do informacji a niewyrządzeniem mu szkody ${ }^{70}$.

Ostatni problem dotyczy odpowiedzialności lekarza związanej z uchyleniem bezprawności jego działania przez poinformowaną zgodę pacjenta - wyraźnie wyrażona wola pacjenta ma walor zwolnienia lekarza $\mathrm{z}$ odpowiedzialności ${ }^{71}$. Zgoda i informacja, oprócz autonomicznych treści, stanowią również zabezpieczenie polegające na odjęciu działaniom lekarza cech bezprawności ${ }^{72}$. Powstaje konflikt między lekarskim obowiązkiem udzielenia informacji, który ogranicza bezprawność a autonomią woli pacjenta, wyrażoną w żądaniu nieudzielenia informacji. Forma udzielenia informacji będąca powinnością lekarza, z jednej strony służy zaufaniu pacjenta do lekarza, wskazuje na autonomię pacjenta, jego prawo do samostanowienia, ale z drugiej zabezpiecza lekarza zgodnie z art. 6 kc. ${ }^{73}$ Należy wskazać, iż pacjent ma prawo do dysponowania informacją i w zaufaniu lekarzowi może zrzec się prawa do informowania. Natomiast lekarz, akceptując to prawo, bierze na siebie cały ciężar nieprzekazanej informacji i w obliczu zgody nieuświadomionej sam podejmuje decyzję. Celem zabezpieczenia interesu lekarza w doktrynie podkreśla się, iż ze względu na skutki, jakie niesie naruszenie obowiązku informowania zawartego $\mathrm{w}$ art. 31 ust. 1 u.z.l. lekarz powinien móc wykazać, że pacjent zażądał nieprzekazywania informacji w sposób bezpośredni i niebudzący wątpliwości.

\section{Wnioski de lege ferenda}

Omówione w artykule wątpliwości zrodziły się na gruncie dość schematycznej regulacji prawa do żądania nieudzielenia informacji. Wobec powyższego można sformułować następujące wnioski de lege ferenda. Za słuszne należy uznać określenie zakresu zrzeczenia i ustawowych przesłanek ograniczenia lub wyłączenia prawa do zrzeczenia się informacji. Ponadto należy podjąć próbę zdefiniowania warunków zrzeczenia i konsekwencji, jakie wywiera na charakter prawny zgody na leczenie. Jed-

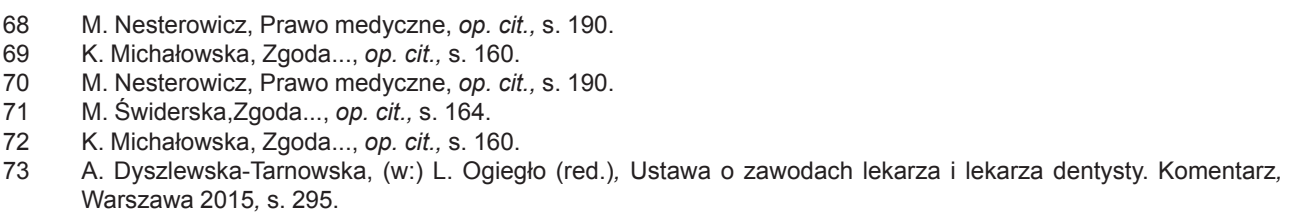


nym z najważniejszych postulatów jest jednak usunięcie różnicy w brzmieniu przepisów ustawy o prawach pacjenta i Rzeczniku Praw Pacjenta oraz ustawy o zawodach lekarza i lekarza dentysty przez ich połączenie, czego skutkiem będzie prawo pacjenta do żądania nieudzielenia informacji, przy utrzymaniu pewnej dyspozycji lekarza co do jej udzielenia, która wynika z obecnego brzmienia przepisu ustawy lekarskiej.

\section{BIBLIOGRAFIA}

Augustynowicz A., Budziszewska-Makulska A., Ustawa o prawach pacjenta i Rzeczniku Praw Pacjenta. Komentarz, Warszawa 2010.

Boratyńska M., Autonomia a granice upoważnienia osoby bliskiej i zaufanej, „Prawo i Medycyna” 2014, nr 1 (54 vol. 16).

Boratyńska M., Konieczniak P., Prawa pacjenta, Warszawa 2011.

Bujny J., Prawa pacjenta między autonomią a paternalizmem, Warszawa 2007.

Drozdowska U., Cywilnoprawna ochrona prawa pacjenta, Warszawa 2007.

Drozdowska U., Wojtal W., Zgoda i informowanie, Warszawa 2010.

Dukiet-Nagórska T., Stosowanie ustawy o zawodzie lekarza przez psychiatrów i ustawy o ochronie zdrowia psychicznego przez lekarzy innych specjalności, „Prawo i Medycyna” 2004, nr 4, (17 vol. 6).

Dukiet-Nagórska T., Świadoma zgoda w ustawodawstwie polskim, (w:) „Prawo i Medycyna” 2000, nr 2 (6/7 vol. 2).

Dyszlewska-Tarnowska A., (w:) L. Ogiegło (red.), Ustawa o zawodach lekarza i lekarza dentysty. Komentarz, Warszawa 2015.

Filar M., Lekarskie prawo karne, Kraków 2000.

Górski A., Leczyć czy nie leczyć? Dylematy podejmowania leczenia z punktu widzenia konfliktu dóbr, (w:) „Czasopismo Prawa Karnego i Nauk Penalnych”, Rok XV: 2011.

Górski A., O obowiązku lekarza poinformowania pacjenta i zgodzie pacjenta na zabieg, „Studia Iuridica" nr 39, 2001.

Grego M., Podstawy i konsekwencje decyzji lekarza o ograniczeniu pacjentowi informacji o jego stanie zdrowia i rokowaniu, (w:) J. Haberko, R.D. Kocyłowski, B. Pawelczyk (red.), Lege Artis problemy prawa medycznego, Poznań 2008.

Karkowska D., Ustawa o prawach pacjenta i Rzeczniku Praw Pacjenta. Komentarz, Warszawa 2016.

Kubicki L., Nowy rodzaj odpowiedzialności karnej lekarza (przestępstwo z art. 192 KK), „Prawo i Medycyna" 2000, nr 8.

Michałowska K., Charakter prawny i znaczenie zgody pacjenta na zabieg, Warszawa 2014.

Michałowska K., Informowanie pacjenta w polskim prawie medycznym, „Prawo i Medycyna” 2003, nr 13 (vol 5).

Nesterowicz M., Prawo medyczne, Toruń 2016.

Nowak W., Prawne formy zgody pacjenta na eksperyment medyczny (zagadnienie cywilnoprawne), „Prawo i Medycyna” 2005, nr 3 (20, vol. 7). 


\section{Karolina Góralczyk}

Sośniak M., Cywilna odpowiedzialność lekarza, Warszawa 1968.

Świderska M., Zgoda pacjenta na zabieg medyczny, Toruń 2007.

Tymiński R., Odpowiedzialność lekarza za udzielenie informacji nadmiernej, „Prawo i Medycyna” 2012, nr 1 (46 vol. 14).

Zielińska E. (red.), Ustawa o zawodach lekarza i lekarza dentysty. Komentarz, Warszawa 2008. 